\title{
Teaching Research and Practice of Logistics Management Major Based on OBE-CDIO - A Case Study of Logistics System Planning and Design Course
}

\author{
Haiou Xiong* \\ Guangzhou Maritime University, Guangzhou 510725, Guangdong Province, China \\ *Corresponding author: Haiou Xiong, 7752833@qq.com
}

\begin{abstract}
The economic and social progress under the new era has put forward new requirements for logistics talents. Based on the teaching concept of OBE-CDIO as well as the training program and objectives of logistics management major in Guangzhou Maritime University, this study analyzes and discusses how the Logistics System Planning and Design course, which is targeted at students majoring in logistics management, enables the students to meet the graduation requirements by virtue of realizing the course objectives.
\end{abstract}

Keywords: OBE; Logistics management; Logistics system planning and design; Teaching research

Publication date: October 2021; Online publication: October 29, 2021

\section{Introduction}

The eminent progress of the world economy as well as science and technology under the new era has called for new requirements in terms of knowledge, skills, and quality structure among logistics talents. Guangzhou Maritime University, the only maritime university in South China, aims to cultivate talents with solid theoretical knowledge, strong practical skills, active innovative and entrepreneurial thinking, as well as high comprehensive quality in order to meet the needs of the industry for senior application-oriented professionals. The logistics management program is to cultivate well-rounded socialist builders and successors with a strong sense for social responsibility and mission as well as systematic knowledge. In particular, students are expected to transform into senior applied professionals who have mastered modern logistics knowledge, familiar with enterprise production and operation activities, capable of innovation, as well as able to engage in the logistics system, its optimization, as well as its supply chain design and management. The concept of outcome-based education (OBE) is result-oriented, and CDIO (conceive, design, implement, and operate) advocates the engineering project life cycle as the carrier, both of which have relatively wide application in professional engineering education. Under the existing concept of new liberal arts education, it advocates interdisciplinary reorganization and the integration of new technologies into philosophy, literature, language, and other courses to provide students with comprehensive interdisciplinary learning ${ }^{[1]}$. It is of valuable significance for logistics management majors to be involved in the research on cultivating interdisciplinary talents, integrating the teaching concept of OBE with CDIO, breaking the traditional education and teaching mode, as well as carrying out the reform of teaching mode in the context of the new era. 


\section{Concept of OBE-CDIO}

Outcome-based education is an outcome-oriented education model, and an engineering education model based on learning outcomes. Compared with the traditional education model, OBE allows students to understand the knowledge learned in each course and solve practical logistics problems in reality. In the process of independent exploration, students' interest in research can be further enhanced. Students actively participate in the process of exploration, research, and creation, giving full play to their subjective initiative. Students can develop their ability of problem identification, problem analysis, and problem solving. Eventually, they would become advanced professionals for enterprises. By introducing OBE into the Logistics System Planning and Design course, students would naturally be placed at the center, their subjective initiative would be highlighted, their self-learning ability and creativity would be cultivated, and their teamwork as well as social competitiveness would be strengthened ${ }^{[2]}$.

The ideology of OBE involves taking students' competency five years after graduation as the starting point, and then designing the training goals and programs based on these competency indicators. In addition, the focus of teachers is on guiding students' independent thinking and cultivating their independent learning skills in the process of teaching. In other words, all teaching activities are designed and carried out in order to achieve student learning outcomes.

CDIO stands for conception, design, implementation, and operation. Through the implementation of CDIO, students' initiative and practicality in the learning process can be improved. It embodies the education mode of "combination of theory and practice" and "task-driven" ${ }^{[3,4]}$.

\section{OBE-based graduation requirements for logistics management major}

Based on the concept of OBE, training objectives, and the situation of the university, the graduation requirements of students majoring in logistics management of Guangzhou Maritime University are shown in Table 1.

Table 1. Graduation requirements for logistics management major

\begin{tabular}{ll}
\hline Graduation requirements & \multicolumn{1}{c}{ Index breakdown of graduation requirements } \\
\hline & 1-1 Humanities and social sciences \\
1. Basic knowledge & 1-3 Computer science \\
& 1-4 Foreign languages \\
& 1-5 Logistics expertise \\
\hline & 2-1 Abilities of logical thinking, systematic thinking, and innovation \\
& 2-2 Ability to identify problems \\
& 2-3 Ability to apply basic principles of management science, mathematics, and social science \\
2. Problem analysis & in identify, express, and analyze logistics management problems through literature research \\
& 3-1 Ability to design solutions for complex logistics problems \\
& 3-2 Creative design of systems and process design to meet the specific needs of logistics \\
& 3-3 Sense of innovation in the design process \\
3. Design/develop solutions &
\end{tabular}

Continued on the next page 


\begin{tabular}{|c|c|}
\hline Graduation requirements & kdown of graduation requirements \\
\hline 4. Research & $\begin{array}{l}\text { 4-1 Application of the principles and methods of logistics science to study the complex } \\
\text { management problems of the profession } \\
\text { 4-2 Design of experiments, analysis, and interpretation of data } \\
\text { 4-3 Reasonable and valid conclusions through information synthesis }\end{array}$ \\
\hline 5. Use of modern tools & $\begin{array}{l}\text { 5-1 Development, selection, or adoption of appropriate technologies, resources, simulation } \\
\text { software, and information technology tools } \\
\text { 5-2 Forecasting and simulation tools }\end{array}$ \\
\hline 6. Management and society & $\begin{array}{l}\text { 6-1 Rational analysis and evaluation of the social, health, safety, legal, and cultural impacts } \\
\text { of solutions to management problems } \\
6-2 \text { Understanding of the responsibilities to be assumed }\end{array}$ \\
\hline $\begin{array}{l}\text { 7. Environment and } \\
\text { sustainable development }\end{array}$ & $\begin{array}{l}\text { 7-1 Understanding and evaluating the impact of management practices for complex logistics } \\
\text { issues on the environment and the sustainable development of the society }\end{array}$ \\
\hline 8. Professional norms & $\begin{array}{l}\text { 8-1 Humanities and social science literacy } \\
\text { 8-2 Social responsibility } \\
\text { 8-3 Management ethics and norms }\end{array}$ \\
\hline 9. Individual and team & $\begin{array}{l}\text { 9-1 The individual role in the team } \\
\text { 9-2 The role of a team member } \\
\text { 9-3 The role of the person in charge in the team }\end{array}$ \\
\hline 10. Communication & $\begin{array}{l}\text { 10-1 Effective communication and exchange } \\
\text { 10-2 Writing of reports and designs, speech and presentation, clear response to instructions } \\
\text { 10-3 International perspective and the ability to communicate and interact in a cross-cultural } \\
\text { context }\end{array}$ \\
\hline 11. Project management & $\begin{array}{l}\text { 11-1 Understanding and mastering the principles of engineering management and economic } \\
\text { decision making } \\
\text { 11-2 Project management skills }\end{array}$ \\
\hline 12. Lifelong learning & $\begin{array}{l}\text { 12-1 Awareness of self-directed and lifelong learning } \\
\text { 12-2 Ability to adapt to changes in interpersonal and work environments }\end{array}$ \\
\hline
\end{tabular}

\section{Realization of the course objectives based on OBE-CDIO}

Given the nature of the course and each graduation requirement, the graduation requirements and specific secondary index that play a major supporting role are determined in a targeted manner: 1, 2, 3, 4, 9, and 12 are major supporting requirements, while 1.5, 2.1, 3.1, 4.1, 9.1, and 12.1 are subgoals. Under the guidance of the general objectives of the course, the general objectives of the course are divided into six subgoals.

Course objective 1: To enable students to master the basic knowledge of system planning and design and its application in logistics practice (supporting graduation requirement 1.5).

Course objective 2: To enable students to have the basic skills to solve practical problems in the field of logistics system planning and design; besides, to understand the basic theory and basic methods of logistics system planning, so as to lay the foundation for competent practical work after graduation (supporting graduation requirement 2.1).

Course objective 3: To enable students to apply basic theories of the knowledge acquired, select reasonable design conditions, and carry out the planning and design of specific logistics systems while taking into account of actual conditions. Students would develop the skill to compare and select design solutions and analyze data (supporting graduation requirement 3.1). 
Course objective 4: Through learning quantitative models, students would understand the content, methods, and processes of logistics system analysis; master the content, methods, and processes of logistics system node, line, and network planning; understand the theory and technology of logistics system planning and design simulation; acquire basic ability in the application of logistics system planning and design. Students would be able to apply the principles and methods of logistics science to study the complex management problems of this specialty (supporting graduation requirement 4.1).

Course objective 5: To enable students to work in small groups as a team to complete relevant case studies assigned in classes and to create slides to share and discuss on stage. In each different design solution, group members will take turns to be the team leader to develop students' communication skills, teamwork, and leadership (supporting graduation requirement 9.1, 9.2, and 9.3).

Course objective 6: Students are required to review relevant advanced design cases as well as the current development of logistics system planning and design outside classrooms to improve their skills in literature retrieval and information acquisition. Students would be able to understand, identify, and judge the key aspects and influencing factors in complex problems faced by logistics systems in a changing environment as well as conduct relevant research, obtain reasonable and effective conclusions, predict future development trends, and develop their sense of innovation (supporting graduation requirement 12.1).

The course achieves its objectives through online and offline classroom teaching, discussion, question and answer (Q\&A), assignments, and examinations to train qualified personnel to meet the professional requirements.

CDIO advocates teaching through actual project cases in order to achieve the training objectives. Based on this concept, students are divided into groups to assume different roles in actual cases to solve problems through teamwork, so as to accomplish the six subobjectives in the course under the corresponding OBE concept ${ }^{[5]}$. The teaching design of the course is shown in Figure 1.

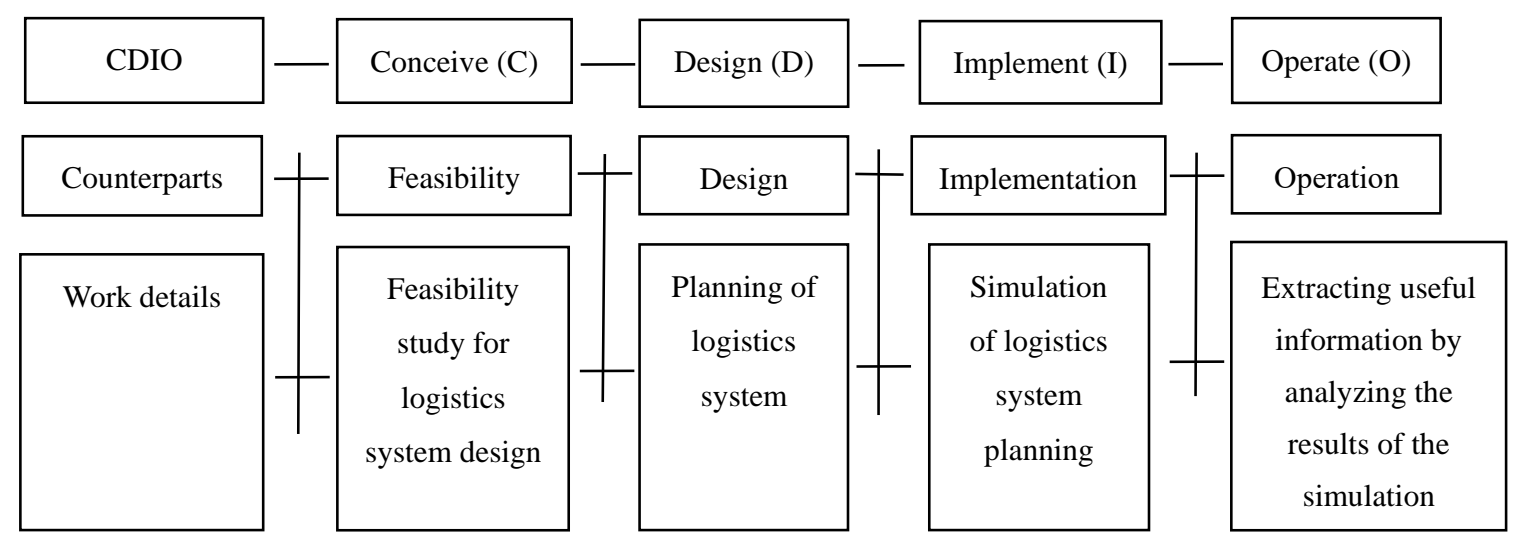

Figure 1. Teaching design of the Logistics System Planning and Design course

\section{Conclusion}

Against the backdrop of the reform of new liberal arts, the curriculum system of the logistics management program is established based on the educational concept of OBE, and its teaching design is based on CDIO in the actual curriculum. In this paper, the Logistics System Planning and Design course is explored and studied as an example to organically integrate the OBE-CDIO concept into classroom teaching. Through the accomplishment of the overall goal, the quality and skills of students would improve, and the objective of professional training is achieved. In the future, new models and new ways of talent cultivation would be explored given the social needs. 


\section{Funding}

This study was supported by the 2019 Guangzhou Educational Science Planning Project (201912027), 2018 Guangzhou Maritime College Innovation and Strong School Project (F410608), 2020 Industry-University Cooperation Collaborative Education Project (Jiao Gao Si Han [2021] No. 3202002325060 , 202002325052, 202002325050), Teaching Quality and Teaching Reform Project of Logistics Engineering Key Major of Guangdong Provincial Undergraduate Colleges and Universities (Yue Gao Han [2020] 19), and Guangzhou Education Policy Research Project (ZCYJ20109).

\section{Disclosure statement}

The author declares that there is no conflict of interest.

\section{References}

[1] Wang D, Li Y, Liu P, 2018, Exploring the Teaching of Planning and Design Class Based on OBE Teaching Concept. Modern Agriculture Research, 2018(10): 79-80.

[2] Li W, Wang Q, 2019, Reform and Practice of Teaching Mode Based on OBE Concept: Taking "Logistics System Modeling and Simulation" Course as An Example. Journal of Heilongjiang University of Technology, (10): 69-72.

[3] Chang Q, Chen J, Huang H, et al., 2021, Design of a Blended Teaching Model for Supply Chain Management Course Based on OBE Concept. Logistics Technology, 40(1): 138-141.

[4] Jue H, Pan B, Miao Z, 2017, Research on Leadership Cultivation of Engineering Talents Based on OBE Concept: Taking Engineering Innovation Design Methodology Course as An Example. Education Teaching Reform, (45): 1-3.

[5] Yang H, Chen Z, 2021, Research and Practice of BIM Curriculum System for Engineering Costing Major Based on OBE-CDIO Concept. University, (27): 42-44. 